\title{
Grazing predation on a population of Ampelisca tenuicornis (Gammaridae: Amphipoda) off the south coast of England
}

\author{
Martin Sheader* \\ Department of Oceanography, University of Southampton, Southampton Oceanography Centre, European Way, \\ Southampton SO14 3ZH, Hampshire, England
}

\begin{abstract}
Grazing impact was assessed for a population of the tubicolous amphipod Ampelisca tenuicornis from a shallow sublittoral muddy-sand community off the east coast of the Isle of Wight, England. Damage resulting from grazing predation or failed predator attack was indicated by the presence of tanned wounds. Almost all damage recorded was to appendages, with the principal feeding structures, the antennae, accounting for $84 \%$ of total injuries and the urosomal appendages accounting for $12 \%$. Pereion and pleon limbs showed little damage. The pattern of injury among appendage groups and the intensity of grazing were both found to be dependent on body size and sex. At maturity, a proportion of time is spent in the water column and this is associated with changes in the pattern of injury and intensity of grazing. Seasonal grazing intensity correlated with temperature and was related to life-cycle characteristics. The intensity, though not the pattern, of grazing was negatively correlated to the abundance of $A$. tenucornis. The impact of grazing on reproductive output was determined. Although grazing on the population was high, rapid regeneration and compensatory feeding appeared to minimise the impact. The length of antennae and their relative proportions are important taxonomic characters used to separate species; if antennal grazing is a common feature of ampeliscid populations, then due care should be taken in selecting undamaged holotype material and in the use of antennal characters in identification keys.
\end{abstract}

KEY WORDS: Ampelisca Predation Grazing - Tube beds

\section{INTRODUCTION}

Living within sediments, and particularly within tubes, provides benthic macro-invertebrates with a degree of protection from predators. However, feeding and defaecation often require the extension of body parts from the tube or burrow, and, when this occurs, the animal may be liable to predation or the extended structure may be subject to non-lethal 'grazing predation' (Trevallion 1971, de Vlas 1981, Ansell \& Gibson 1990, Ansell 1995). To minimise grazing impact, many species reduce or optimise the time when body structures are extended and available, and most have the capacity to regenerate lost body parts rapidly.

\footnotetext{
-E-mail: ms3@mail.soc.soton.ac.uk
}

Grazing predation appears to be widespread in shallow benthic systems (Ansell 1995), though most studies to date have considered only large invertebrates, especially ophiuroids, molluses and polychaetes, with little information available on crustaceans. However, one family of amphipod crustaceans, the Ampeliscidae, is common in marine sediments throughout the world and certain species may occur at very high densities in coastal sediments, forming tube beds or mats (BellanSantini \& Dauvin 1988). All ampeliscids, with the exception of those living on hard substrata, are tubedwelling (Bellan-Santini \& Dauvin 1988) and as such, in common with other tubicolous species, they may greatly modify the substratum by their presence (Mills 1967, Wooding et al. 1973, Nowell \& Church 1979, Luckenbach 1986j, they may influence exchange processes at the sediment-water interface (Nowell \& 
Church 1979, Aller 1982), and they may be major contributors to macrofaunal production (Sanders 1956, Klein et al. 1975, Sheader 1977, Dauvin 1988). Therefore they are often a major food resource for a wide variety of demersal organisms (e.g. predatory polychaetes and crustaceans, demersal fish, grey whales) (Summer 1980, Bellan-Santini \& Dauvin 1988, Dauvin 1988).

The ampeliscid amphipod Ampelisca tenuicornis Lilljeborg, 1855, is found in shallow coastal fine muddy-sands (Sheader 1977). It constructs a flattened flexible mud-covered tube, extending 5 to $10 \mathrm{~mm}$ above the sediment surface. When feeding, the amphipod supports itself, ventral side uppermost, at the mouth of the tube, attached to the tube margin by the dactyls of the posterior pereiopods. The first pair of antennae are held vertically, whilst the second longer pair are used to collect food (detritus, larvae, small epibenthic organisms) either from the sediment surface or from the overlying water. The second antennae are able to rotate rapidly to produce a current (reinforced by a flow produced by the pleopods), drawing to the antennae potential food particles, which are subsequently captured and transferred to the anterior pereiopods and mouthparts (Kanneworff 1965). During feeding therefore, the antennae and anterior part of the head (including eyes with cuticular lenses), the dactyls of the posterior pereiopods and, during defaecation, the urosome may project from the tube. The large and active second pair of antennae, the main food-collecting structures, are likely to be the most conspicuous projections, their rapid movement attracting the attention of both predators and small epibenthic grazers. When mature, both male and female $A$. tenuicornis may be found nocturnally in the water column (Dauvin \& Zouhiri 1996), where they are subject to a different suite of pelagic predators.

Damage, especially to appenclages, is common in. amphipod species (personal observations on a wide range of amphipod species). It can be the result of predator attack, grazing predation, intra-specific aggression or accident. In crustaceans, wounds are sealed rapidly by blood clotting; the damaged area is subsequently hardened by tanning (Halcrow \& Smith 1986, Halcrow 1988). Depending on the extent of damage, appendages or body parts are regenerated over one or more moults. However, for the duration of the intermoult period in which the damage has occurred, the wound, sealed with its dark tanned plug, is readily evident.

This study examines and quantifies patterns of nonlethal injury (detected by the presence of tanned injuries) in a dense population of Ampelisca tenuicornis occurring at a shallow-water site on the south coast of England. The observed patterns are related to life-cycle characteristics and ecology of the species.

\section{METHODS}

Specimens of Ampelisca tenuicornis were collected as part of a long-term study at a site $\left(50^{\circ} 42.7^{\prime} \mathrm{N}\right.$, $01^{\circ} 03.6^{\prime} \mathrm{W}$ ) to the east of the Isle of Wight on the south coast of England. Water depth at the site is 7 to $9 \mathrm{~m}$ and the sediment is a fine muddy-sand. The abundance of A. tenuicornis varied spatially and seasonally, reaching a maximum of about $40000 \mathrm{~m}^{-2}$ in late summer (author's unpubl, data).

Samples used in the study were collected at approximately monthly intervals over a 2 yr period (1993-1994). On each sampling occasion, five $0.1 \mathrm{~m}^{2}$ van Veen grab samples were collected, and temperature was recorded at $1 \mathrm{~m}$ above the sea floor. The sediment was washed immediately through a $0.5 \mathrm{~mm}$ aperture sieve and the material retained fixed within $10 \mathrm{~min}$ of collection. Samples were preserved with $10 \%$ formaldehyde and stained with Rose Bengal to aid subsequent sorting.

In the laboratory, all Ampelisca tenuicornis were picked from samples by sorting under a low power stereomicroscope. Approximateiy 50 A. ienuicornis were removed at random from each grab sample. Each amphipod was processed to record body length (anteriormost point of head to posteriormost tip of telson), sex (males: presence of penes; females: presence of oostegites or oostegite buds), degree of maturity (immature juveniles: no secondary sex characteristics evident; immature females: presence of oostegite buds; mature females: fully developed oostegites forming marsupium; immature males: presence of penes, antennae undeveloped; mature male: fully developed penes, antennae long with additional aesthetascs) and, if damaged, the pattern of injury. Injury was recorded under the following 17 location categories: antennae (A1 and A2), pereiopods (P1 to P7), pleopods (PL1 to PL3), uropods (U1 to U3), telson (T) and other injuries (O). Amphipods with untanned wounds were assumed to have been damaged during processing and were discarded. These amounted to less than $0.05 \%$ of the total amphipods processed.

Twenty grab samples, taken over a range of Ampelisca tenuicornis densities, were collected in April 1994 to determine the impact of density-dependent factors on the observed pattern of injury. Samples were processed as for the monthly samples.

A small number (24) of live amphipods were collected and returned to the laboratory, where antennae or selected limbs were removed to determine the time for development of a tanned cicatrice and regeneration of appendages. The 24 live Ampelisca tenuicornis collected were divided into 3 groups. The amphipods ranged in size from 2 to $8 \mathrm{~mm}$, and each of the 3 groups contained a complete range of sizes. In the 
first group, the second antennae (A2) were removed leaving 3 or 4 peduncle segments; in the second group, fifth pereiopods (P5) were removed at the level of the ischium; and in the third group, the third uropods (U3) were completely removed. The amphipods were examined every $10 \mathrm{~min}$ and the progress of wound healing noted. The amphipods were maintained on fine sand in aerated seawater, which was changed daily. A range of senescent algal cultures was used as food. The amphipods survived well, with 21 alive after 2 mo.

\section{RESULTS}

\section{Time to form tanned cicatrice}

Tanning of wounds took a similar time for the 3 groups of experimentally injured Ampelisca tenuicornis. Tanning was first evident after $30 \mathrm{~min}$, with complete tanning of wounds after 1.5 to $2 \mathrm{~h}$. No tanning was evident in the first 20 min.

Three individuals from each of the experimental groups were fixed in $10 \%$ formaldehyde solution immediately after injury and monitored as controls. No tanned wounds formed in this experimental group.

Processing time of grab samples in the field (time from collection to sieving and fixation) was, in each case, less than $10 \mathrm{~min}$. Any tanned wounds noted on specimens of Ampelisca tenuicornis must therefore have occurred prior to capture.

\section{General pattern of injury}

The general pattern of injury for the whole data set is shown in Table 1. For the purposes of comparison among groups, data are given as derived percentages. Injuries were almost invariably to the appendages, with very few injuries to the body.

For the whole population over the $2 \mathrm{yr}$, approximately $76 \%$ of injuries were to the $A 2$, the primary food-gathering appendages. A1 and A2 together accounted for $84 \%$ of injuries. The uropods and telson together accounted for $12 \%$ of injuries. Damage to pereiopods was low (2.5\% of injuries). Using the raw data ( $n=1288$ ), rather than the derived percentage data given in Table 1, for the 17 groups of appendages, the null hypothesis, that injuries were homogeneously distributed among appendages, was rejected ( $G=48.69, \mathrm{p}<0.01)$. Similarly, when the data were arranged into 3 size groups, the null hypothesis was rejected $(p<0.01)$ in each case, confirming that damage to $\mathrm{A} 2$ was significantly greater than for other appendages.

The pattern of injury was different for amphipods of different size categories. Using raw data, rather than derived percentages, the size groups were compared pair-wise using the $G$ statistic. To simplify the data, injured appendages were grouped into 5 categories (group 1: A1; group 2: A2; group 3: P1 to P7; group 4: PL1 to PL3; group 5: U1 to U3 and T). Calculated values of $G$ exceeded tabulated values in each case $(<4.0 \mathrm{~mm}$ vs $4.0-5.9 \mathrm{~mm}: G=28.69, \mathrm{p}<0.01$; $4.0-5.9 \mathrm{~mm}$ vs $\geq 6.0 \mathrm{~mm}: G=10.36, \mathrm{p}<0.05 ;<4.00 \mathrm{~mm}$ vs $\geq 6.0 \mathrm{~mm}: G=19.72, p<0.01$; confirming that the frequency of injury across the 5 appendage categories differs between each pair of size groups. Small Ampelisca tenuicornis (<4.0 mm) had a high percentage of recorded injuries to the antennae (A1 and A2: $92.4 \%$ ) and moderately low percentage of injury to the urosome ( $\mathrm{U} 1$ to $\mathrm{U} 3$ and $\mathrm{T}$ : $7.1 \%$ ). In contrast, for the larger size groups, injuries to the antennae, although remaining high, were somewhat reduced $(4.0-5.9 \mathrm{~mm}: 81.2 \% ; \geq 6 \mathrm{~mm}: 83.2 \%)$, though the percentage of injuries to the urosome was greater $(4.0-5.9 \mathrm{~mm}: 15.5 \%$; $\geq 6 \mathrm{~mm}: 11.8 \%)$.

Females matured at a body length of 5.5-6.0 $\mathrm{mm}$ and males at $6.5-7.0 \mathrm{~mm}$. Once mature, males were recorded in the benthic samples very infrequently, but females were abundant. At this stage, males become pelagic. Females in the latter half of the moult cycle (often carrying late eggs or juveniles in the marsupium) may also make nocturnal migrations into the water column (Dauvin \& Zouhiri 1996). A comparison was made between patterns of damage recorded in injured mature males and mature females from summer samples. Since the number of mature males in

Table 1. Ampelisca tenuicornis. Percentage of injury to appendages for 3 size categories and for total samples. A: antennae; P: pereiopods; PL: pleopods; U: uropods; T: telson

\begin{tabular}{|lccccccccccc|}
\hline Size & A1 & A2 & P1-2 & P3-4 & P5-7 & PL1-3 & U1 & U2 & U3 & T & Other \\
\hline$<4 \mathrm{~mm}$ & 8.8 & 83.6 & 0 & 0 & 0.5 & 0 & 2.4 & 1.2 & 2.9 & 0.6 & 0 \\
$4-5.9 \mathrm{~mm}$ & 9.4 & 70.8 & 0.7 & 0.7 & 1.5 & 0.8 & 1.4 & 1.8 & 9.4 & 2.9 & 0.7 \\
$\geq 6 \mathrm{~mm}$ & 5.1 & 78.1 & 0 & 1.5 & 2.0 & 0.5 & 0 & 1.5 & 7.7 & 2.6 & 1.0 \\
Total & 7.9 & 76.4 & 0.3 & 0.8 & 1.4 & 0.5 & 1.2 & 1.6 & 7.1 & 2.2 & 0.6 \\
\hline
\end{tabular}


Table 2. Ampelisca tenuicornis. Percentage incidence of damagge to the antennae and urosome in injured mature males and females. Number in each category is given in parentheses

$\left[\begin{array}{lcc}\text { Sex } & \begin{array}{c}\% \text { of damage } \\ \text { to antennae }\end{array} & \begin{array}{c}\% \text { of damage } \\ \text { to urosome }\end{array} \\ \hline \text { Mature males } & 71.3(214) & 28.7(86) \\ \text { Mature females } & 87.7(263) & 12.3(37)\end{array}\right]$

samples was small, additional specimens were collected by using near-bottom plankton tows. As most damage (>96\%) was to the antennae and urosome, only these 2 sites were considered. Three hundred damaged mature females were compared with the same number of damaged mature males. The results are presented in Table 2. Male and female data were significantly different ( $G$-test, using Williams correction, $G=24.99, p<0.01$ ). The males showed proportionally greater damage to the urosome and less damage to the antennae than did the females, reflecting their availability to different suites of predators.

The second antennae (A2) are the main appendages dealing with the capture of food, and therefore their damage might be expected to be associated with reduced food ingestion and/or increased compensatory feeding activity. Of those individuals with damage to the second antennae, $74.0 \%$ had damage to only one $\mathrm{A} 2$, and $26.0 \%$ to both $\mathrm{A} 2$ (the 3 size categories do not differ significantly).

The degree of damage to A2 varied in a similar way for the 3 size categories. Of the damaged A2 recorded, $12.7 \%$ had damage to the terminal flagellar segment only, $15.5 \%$ had lost the distal quarter of the flagellum, $31.4 \%$ had lost half the flagellum, $16.7 \%$ had lost three-quarters of the flagellum and $23.7 \%$ had damage extending into the peduncle.

Evidence from the amphipods maintained in the laboratory showed that recovery from injury to the proximal half of the antenna was rapid, usually producing a functional appendage after the next moult (depending on the point in the intermoult period when injury occurred). More severe damage extending to the distal half of the antenna usually required 2 moults to produce a functional appendage.

\section{Frequency of injury}

There was a clear pattern in the frequency of injuries per individual (Fig. 1). Amphipods at a body length of $<6 \mathrm{~mm}$ had 1.0 to 1.5 injuries, and those $\geq 7 \mathrm{~mm}$ had 2.0 to 2.5 injuries. The latter group were mostly mature males. The $6.0-6.9 \mathrm{~mm}$ group had intermediate injury values and consisted mainly of mature females.

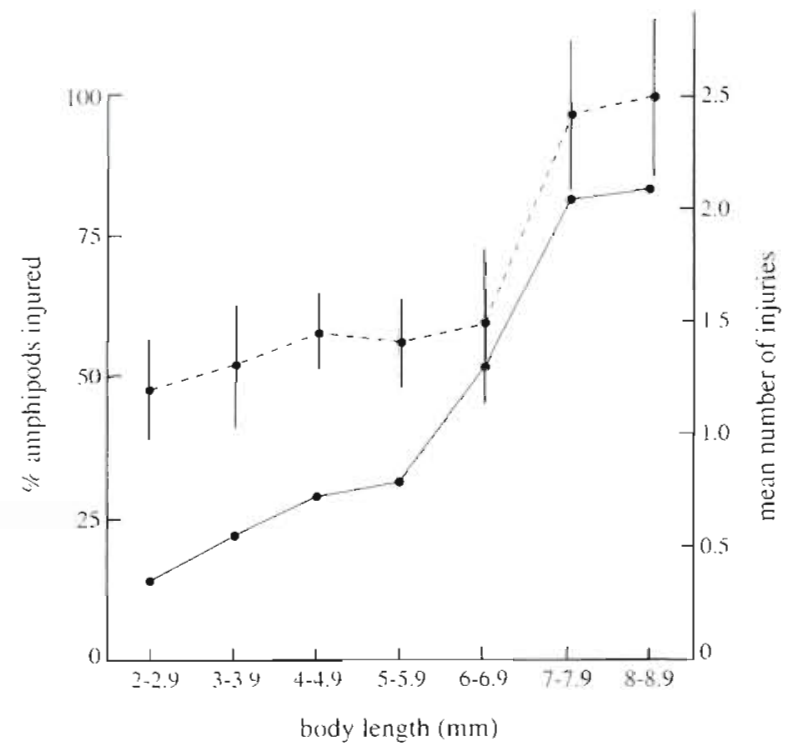

Fig. 1 Ampelisca tenuicornis. Change in the percentage of individuals injured (solid line) and the mean ( $(\mathrm{SD})$ number of injuries per damaged individual (dashed line) relative to body length

There was an increase in the percentage of injured amphipods as body size increased (Fig. 1). Most individuals in the $6.0-6.9 \mathrm{~mm}$ class were mature females, whilst most $>7 \mathrm{~mm}$ individuals were mature males. The frequency of injured mature males $(n=366$, $82 \%$ damaged) differed from that of mature females ( $\mathrm{n}=789,38 \%$ damaged) (G-test, Williams correction, $G=49.09, \mathrm{p}<0.01$ ).

Although the data indicated that the proportion of injured amphipods increases with increasing body length, this is not a good indication of rate of injury, since the length of the moult cycle (and hence opportunity to incur damage) is body-size dependent. There are no data in the literature on the relationship between temperature, body length and intermoult in ampeliscids, though other gammarid species have been studied. Using intermoult data collected as background for a previous study of Ampelisca tenuicornis (Sheader 1977), rate of injury was calculated for the different size groups (Fig. 2). The intermoult data used was for a single temperature $\left(16^{\circ} \mathrm{C}\right.$, equivalent to summer temperature at the sample site) over a range of body sizes. All amphipods were assumed to be half way through their intermoult period and rate of injury was therefore calculated as the proportion injured divided by half the appropriate intermoult period. Since amphipods in the current study were collected over a 2 yr period, and intermoult values at summer temperatures are used to calculate injury rate, the values in Fig. 2 provide at best an index of injury rate adjusted to summer temperatures. 


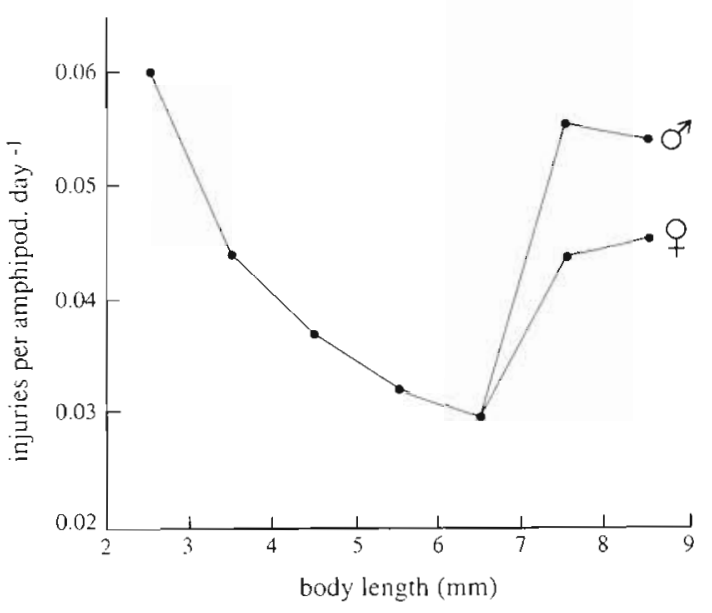

Fig. 2. Ampelisca tenuicornis. Estimated number of injuries per amphipod per day relative to body length

Values of the injury rate index were highest for the smallest size category, falling with increase in size to reach a minimum value (about half that at $2-2.9 \mathrm{~mm}$ ) at 6-6.9 $\mathrm{mm}$. Mature males and females showed a marked increase in injury rate, probably associated with increased pelagic activity.

\section{Seasonal pattern of injury}

Fig. 3 shows the percentage of animals injured in each month. Values varied between minima of around $15 \%$ in winter/spring and maxima of 40 to $50 \%$ in summer. Spearmans rank correlation was applied to the water temperature and percentage injury data. The value of $r_{S}(0.567)$ exceeded the tabulated value from which it can be inferred that the 2 variables are positively correlated $(p<0.05)$. However, injury minima and maxima did not coincide with temperature minima and maxima, suggesting that a range of other

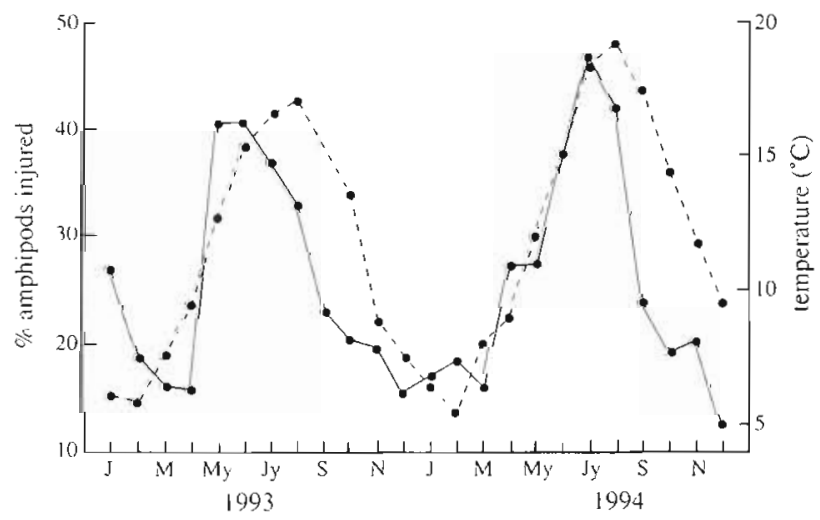

Fig. 3. Ampelisca tenuicornis. Seasonal cycle in the percentage of amphipods injured (solid line) and temperature (dashed line) factors (biotic or abiotic) might be influencing the intensity of grazing predation and hence injury.

As this study has shown that body size influences the proportion of injured individuals, the population size frequency would be expected to influence seasonal patterns. Fig. 4, based on size-frequency histograms for the 2 yr period, shows changes in mean size of individuals in the dominant cohorts. Ampelisca tenuicornis has a bivoltine life-cycle strategy, with several cohorts produced per generation (Sheader 1977, Dauvin 1988). The population in the present study conforms to this pattern, but differs in the number of summer cohorts produced and the maximum body size achieved at maturity. There were clear patterns of growth and reproductive activity throughout the year, differing slightly between years. During winter (October/November to February/March) there was little or no growth. At this time, the population was dominated by a single cohort (about 3.0-3.5 mm body length), though in 1994 a small number of large individuals (mean size $5.5 \mathrm{~mm}$ ) overwintered. Dauvin (1988) found similar between-year variation at one of his English Channel sites. With increase in temperature (above about $8^{\circ} \mathrm{C}$ ) in spring and early summer (April to June), the amphipods entered a phase of rapid growth. Maturity was achieved and egg production occurred during summer $\left(>13^{\circ} \mathrm{C}\right.$, May/June to September), with females producing a succession of synchronised broods (cohorts). The resulting offspring matured rapidly and reproduced to provide the overwintering cohort (as in 1993), but, if produced late in the year (as in 1994), a small proportion over-wintered as large (about $5.5 \mathrm{~mm}$ ) individuals. Summer cohorts generally survived for 3 to $5 \mathrm{mo}$, whereas overwintering cohorts survived up to 12 to 13 mo.

During the over-wintering period (1993: JanuaryFebruary and November-December; 1994: JanuaryMarch and October-December), there was no growth evident. The percentage of amphipods with injury was

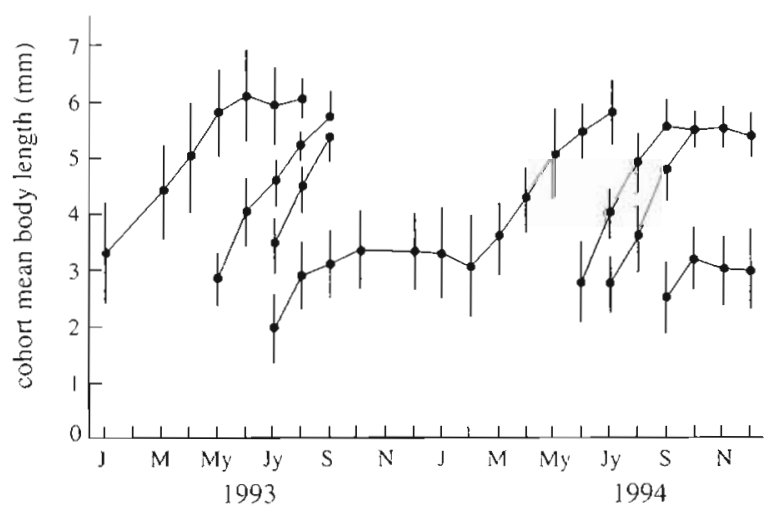

Fig. 4. Ampelisca tenuicornis. Interpretation of seasonal sizefrequency data, showing changes in mean $( \pm \mathrm{SD})$ body length of cohorts 
low (average value 18.9\%) and most injuries were to the antennae (especially A2), with relatively few injuries to the urosome.

In the spring period of rapid growth (1993: March-May; 1994: April-June), the percentage of injuries increased (average value $31.4 \%$ ), with most damage to the antennae, but with an increased proportion of damage to the urosome.

The summer/autumn months (1993: May-September; 1994: June-September) were characterised by both rapidly growing juveniles and mature males and females. Mature males occur predominantly in the water column. However, only mature females approaching moult are found in the water column, and then only nocturnally. The percentage of damage was at its greatest (average value $42.6 \%$ ) in these summer/autumn samples. Most damage was to the antennae, but with a significant proportion of damage to the urosome. Although the percentage damage to the urosome was less than in the actively growing spring individuals, because of the higher percentage of injured individuals, the absolute number of injuries to the urosome (and to the antennde) increased.

\section{Density-dependent effects}

Twenty $0.1 \mathrm{~m}^{2}$ grab samples were taken in April 1994 within the sampling area. Samples were collected across the site in order to select a broad range of Ampelisca tenuicornis densities. A. tenuicornis was patchily distributed, and numbers varied from 4 to 3129 per $0.1 \mathrm{~m}^{2}$ April was selected as a period when relatively few $A$. tenuicornis were likely to be pelagic, the patterns of injury reflecting the intensity of benthic grazing/predation. Results are showm in Fig. 5. Spearman's rank correlation was applied to the data. The value of $r_{S}(-0.607)$ exceeded the tabulated critical value of -0.592 at $p=0.01$, indicating that the inverse correlation is highly significant. The pattern of limb damage did not change significantly at different densities, with about $80 \%$ damage to the antennae and about $15 \%$ damage to the urosome.

\section{Impact of injury on reproductive output}

The pattern of oocyte development and growth is similar in most boreal shallow-water gammarids studied (see Sheader 1983). Oogonia are generated in the ovary and develop over 2 intermoult periods. During the first intermoult period there is little growth. During the second intermoult period, oocyte growth is initially slow, but becomes rapid during the latter half of the moult cycle as yolk is incorporated (Sheader

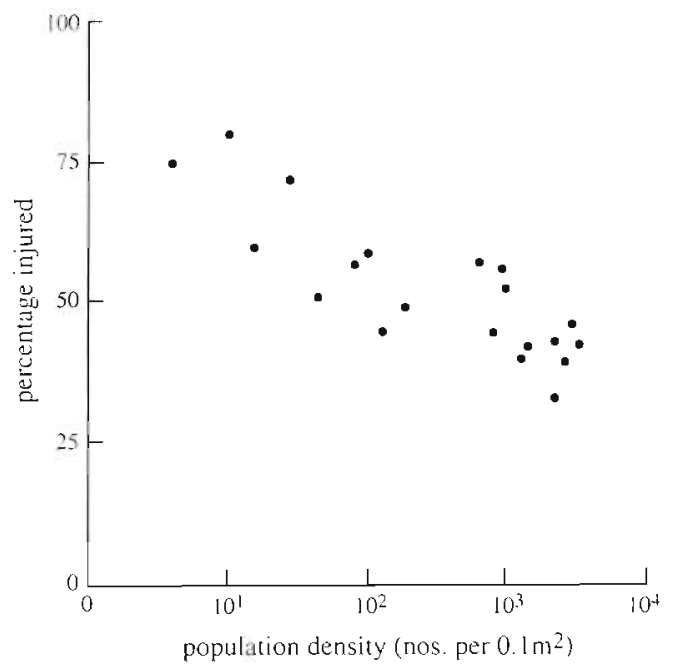

Fig. 5. Ampelisca tenuicornis. Relationship between the percentage injured and population density for samples collected in April 1994

1983). Starvation of females during the period of yolk deposition has been shown to bring about resorption of some or all the developing oocytes (Sheader 1983 for Gammarus duebeni). As the A2 are the main foodcollecting appendages in ampeliscids, it might be expected that damage during or prior to this critical period could impact on oocyte development and reproductive output

Observations of laboratory-maintained Ampelisca tenuicornis in this study showed that slight damage to A2 (e.g. loss of distal quarter of flagellum) was almost completely repaired at the following moult. However, major damage (e.g. loss of flagellum and part of peduncle) required 2 moults to effect an adequate repair. After the first moult following injury, females with major A2 damage were recognised by the possession of a very short antennal flagellum. This therefore provides a means of recognising females that had severe antennal damage during the period when yolk should have been incorporated into the developing oocytes

To test the impact of A2 injury on egg production, mature females collected in the June-August period were used. Brood size is dependent on female body length (Sheader 1977), and therefore to reduce the impact of female size on egg output, body length was standardised by randomly selecting individuals within the $6-7 \mathrm{~mm}$ size range. Egg mortality during brooding is a common feature of many amphipods (Sheader 1983) and therefore only females in the first half of the intermoult period were selected. These were recognised as either carrying early eggs (Stage I-II; see Sheader 1983) in the marsupium or as having an empty marsupium but with early oocytes in the ovaries lack- 
Table 3. Ampelisca tenuicornis. Mean brood size and the percentage of females brooding in the 3 groups of females (1. no damage ${ }_{2}$; one $\mathrm{A} 2$ damaged; 3 : both $\mathrm{A} 2$ damaged)

\begin{tabular}{|ccc|}
\hline Group & $\begin{array}{c}\text { Mean egg number } \\
\text { per brood }( \pm \text { SD) }\end{array}$ & $\begin{array}{c}\text { Percentage of females } \\
\text { brooding }\end{array}$ \\
\hline 1 & $13.78 \pm 5.45$ & 100.0 \\
2 & $11.95 \pm 5.02$ & 95.0 \\
3 & $8.29 \pm 4.79$ & 67.5 \\
\hline
\end{tabular}

ing yolk. Three groups of females (40 per group) were chosen for comparison: Group 1: mature females with no apparent damage to either A2; Group 2: mature females with damage to a single A.2, healed and regenerating, but with a small flagellum; Group 3: mature females with both $\mathrm{A} 2$ healed and regenerating, but with small flagella. The 3 groups therefore represent 3 levels of damage to the major feeding structures during the period of oocyte development. The groups of females are compared in Table 3 in terms of the percentage of females brooding (carrying eggs in the marsupium) and in terms of the mean number of eggs recorded within the marsupia of those females that are brooding

The mean number of eggs carried by brooding females was compared using the $t$-test. Groups 1 and 2 were not significantly different. Group 3 was found to be significantly different $(p<0.01)$ to both Group 1 and Group 2.

The G-test with Williams correction was used to compare the number of females brooding or not brooding among groups. Once again, Groups 1 and 2 proved not to differ significantly, and Group 3 proved to be significantly different $(p<0.01)$ to Groups 1 and 2 .

Severe injury to one A2 during oocyte development appears therefore to have little or no impact on reproductive output as measured by brood size (egg number per brood) and the proportion of females producing a brood; injury to both $\mathrm{A} 2$ has a more significant impact, reducing brood size by about $40 \%$ and reducing the number of females producing a brood by about $33 \%$. The exact timing of such damage within the intermoult period is likely to determine whether or not a brood is produced and, if so, the number of eggs it contains.

\section{DISCUSSION}

The trophic energetics of marine systems are often complex and frequently do not fit simplistic models of predator-prey interaction. Such is the case with many sedentary benthic species which need to extend body structures above the sediment surface to feed and/or defaecate. Grazing of such structures is well documented for ophiuroids, bivalve molluscs and certain polychaetes (Trevallion 1971, de Vlas 1981, 1985, Ansell 1995), though is seldom quantified. These species have the ability to repair damage rapidly and the body structure is such that important internal organs are unlikely to be damaged by this sort of predation. Grazing may, however, impose a significant metabolic cost on the prey species, which must resolve the conflict of need for essential contact with the sediment surface and risk of predation. Some macrofaunal species avoid visual predators or grazers by extending feeding structures only at night (Dugan 1981, Hughes et al. 1983. Evans 1987), whilst others show no such restrictions (e.g. Donax vittatus and Lanice conchilega; Ansell 1995). For benthic populations, grazing predation may represent an energetic cost both in terms of lost somatic production and by reducing feeding efficiency and hence food intake.

There have been no studies of grazing predation on Crustacea, though crustaceans have mechanisms of wound repair and regeneration which provide useful and ready indicators of damage. Such injury may be the result of attempted predation, grazing predation, intra-specific aggression or accident, but in tubicolous sedentary species, such as Ampelisca tenuicornis, attempted predation and grazing predation are likely to be of greatest significance.

Tubicolous species may form dense beds, providing a 'lawn' of feeding appendages for potential browsers. Most of the larger macrofaunal species studied (e.g. molluscs, ophiuroids, polychaetes) are thought to be grazed predominantly by fish and decapod crustaceans, actively moving over and feeding at the sediment-water interface. The feeding structures of ampeliscids are considerably smaller than those of other species studied and are probably eaten by a range of small epibenthic predators including peracarid crustaceans, polychaetes, post-larval fish and juvenile decapods.

Results of this study indicate that, for Ampelisca tenuicornis, the primary feeding structures (A2) and those structures associated with defaecation (the urosome) receive the greatest amount of damage, with relatively little injury sustained by the pereion and pleon. The pattern of damage suggests that this is predominantly the result of grazing predation. The relative proportion of damage to the antennae and urosome is size dependent, which can be interpreted as reflecting damage imposed by different suites of consumers. Alternatively, the same suite of grazers could be preying on all size categories but at different sizerelated efficiencies.

Mature males and females differed significantly, both in terms of the pattern of injury sustained and the 
proportion of individuals injured. Mature males are found chiefly in the water column. Females carrying late eggs/juveniles or close to moulting can be nocturnally pelagic: at this time, males and fumales are essentially suprabenthic (abundant in the bottom metre or so), though with male distribution extending towards the surface (Dauvin \& Zouhiri 1996). It has been suggested that Ampelisca species move into the water column to mate (Mills 1967, Borowsky \& AitkenAnder 1991, Dauvin \& Zouhiri 1996), though the presence of females carrying late eggs may indicate that nocturnal migrations may also aid in the dispersal of such females and their offspring (Mills 1967). Whatever the reason for the pelagic migration, the amphipods, once mature, are subjected to different suites of predators. It is unclear from the literature whether males become wholly pelagic once mature and whether individuals continue to feed. It is, however, clear that females bchave differently, on occasion leaving the sediment nocturnally during the latter half of the intermoult period, but returning to the sediment during the day, presumably to feed and possibly to avoid predation. The rate and frequency of injury increases as males and females mature, when behavioural changes make them susceptible to a wider range of predators, both pelagic and benthic. Mature males, which spend more time in the water column, have a greater proportion of individuals damaged, suggesting that the water column is more hazardous in terms of predation. Also, an increased proportion of damage is to the urosome, perhaps reflecting failed capture attempts by pursuing predators.

The frequency of injury and number of injuries per amphipod are clearly size dependent, though this is partly influenced by size-dependent changes in intermoult period and by seasonal impact on size frequency. Large individuals are present in summer when temperature is high, feeding intensive and grazing predation high, whereas small individuals dominate in winter. An attempt to resolve the importance of intermoult period using summer intermoult figures suggested that the rate of injury is highest in the smallest size category, falling with increase in size, but increasing, for both females and males, in the larger size categories. Again, mature males have significantly greater rates of injury than mature females, indicating their increased availability to pelagic predators.

Seasonal changes in grazing damage are clear and correlate significantly with temperature. Winter is a period of no apparent growth in the Ampelisca tenuicornis population, suggesting reduced feeding activity. Absence of growth coupled with a probable reduction in predator activity at low temperature result in a minimum in the level of grazing predation. Intermoult period in coastal temperate amphipods is negatively related to temperature for a given body size (Sheader 1983, for Gammarus duebeni) and so would be longer in winter and shorter in summer. Winter and summer values of the proportion of injured individuals (as shown in Fig. 3) are therefore indicative of much lower and higher rates of injury respectively than Fig 3 would suggest.

Summer months are periods of intensive feeding, breeding and growth in the Ampelisca tenuicornis population. Grazing predation reaches a maximum at this time as a consequence of increased availability to predators and increased predator activity at higher summer temperatures.

Relatively few large females (>7 $\mathrm{mm}$ ) were recorded in this study compared with similar English Channel populations (Dauvin 1988). The study site is a relatively small area (about 100 ha) of muddy-sand, with coarser sand inshore supportıng Ampeisca brevicornis, and muddy gravels over much of the surrounding area supporting $A$. diadema. The absence of large mature females may be the result of horizontal transport out of the ared during nocturnal migration, bringing about a rapid decline in the population once maturity is reached. Sufficient females must be retained to maintain the population.

There is a negative correlation between the proportion of the population injured and population density. It might be assumed that feeding on high-density beds would be more cost-effective for predators/grazers if they are to optimise their food input. At high Ampelisca tenuicornis density, predators may disturb adjacent amphipods, causing them to withdraw into their tubes. Also, at very high density, there may be interactive disturbance between individual prey, resulting in waves of disturbance and withdrawal around grazers. The precise interpretation is complicated by the presence of a range of predator and prey species at the sediment-water interface. The observed inverse density-dependent functional response is of a type frequently recorded for invertebrate predatorprey interactions (Putman \& Wratten 1985). Holling (1959) derived a model which fits this type of response to predation; the response was interpreted as a consequence of an increase in the proportion of searching time occupied in dealing with prey as their density increased. The density-dependent predator-prey and intra-specific prey interactions, suggested for the $A$. tenuicornis population, could have a similar impact on predator searching time.

Most benthic species that are subjected to grazer predation show adaptations which allow them to with.stand grazing damage. These adaptations include rapid regrowth of projecting body parts and optimisation of temporal patterns of feeding and/or defaecation 
to reduce the likelihood of grazing (Ansell 1995). There is no published information on feeding patterns in ampeliscids, but the present study indicates that regeneration of grazed antennae and urosome appendages is generally rapid ( 1 to 2 moult cycles) in Ampelisca tenuicornis.

With a knowledge of intermoult duration, size-frequency and seasonal changes in the proportion of the population injured, an approximate figure can be calculated for the number of injuries experienced during the lifetime of an average individual. This is approximately 13 to 14 grazing injuries per individual over a 12 to 13 mo lifespan. Each injury is insignificant in terms of somatic production, generally accounting for less than $1 \%$ of body weight. In a species such as Ampelisca tenuicornis, which may be subject to a high level of grazing pressure, adaptations to minimise the impact of grazing would be expected. The results of this study show that loss of one A2 has little effect on reproductive output, which suggests that damage results in compensatory feeding activity using the remaining single A2. Loss of both $A 2$ has a major impact on reproductive output, either preventing egg production or significantly reducing brood size. Complete loss of the flagella from both $\mathrm{A} 2$ is, however, relatively rare. Of all mature females examined, around 35 to $40 \%$ exhibited damage to $\mathrm{A} 2$, but only $2.5 \%$ of mature females had severe damage (complete loss of flagella) to both A2. In the majority of individuals, injury to the antennae may result in compensatory feeding, resulting in no reduction in brood size. Any damage to appendages does, however, require regeneration, and compensatory feeding using a single A2 may be less energy efficient. Such changes are likely to alter energy budgets and possibly impinge on growth. A detailed study of the impact of injury on energy budgets in grazed populations would be of value, if the ecology and energetics of such species are to be fully understood.

Although the population of Ampelisca tenuicornis studied is heavily grazed, as with other macrofaunal species studied, individuals appear to be adapted to cope with moderate and frequent levels of damage.

The length of the antennae and their relative proportions are important taxonomic characters used to identify Ampelisca species. If grazing is a common feature of ampeliscid populations, then this will have implications for the selection of holotype material (J.-C. Dauvin pers. comm.) and the use of antennal characters in identification keys.

Acknowledgements. I thank Grant Rowe for collecting most of the samples used in this study and Stephen Coling for undertaking a preliminary study of the material.

\section{LITERATURE CITED}

Aller RC (1982) The effects of macrobenthos on chemical properties of marine sediment and overlying water. In: McCall PL, Trevesz MJS (eds) Animal-sediment relationships. Plenum Press, New York, p 53-102

Ansell AD (1995) Surface activity of some benthic invertebrate prey in relation to the foraging activity of juvenile flatfishes. In: Eleftheriou A, Ansell AD, Smith C.J (eds) Biology and ecology of shallow coastal waters. 28th Eur Mar Biol Symp, Crete, 1993. Olsen and Olsen, Fredensborg, p 245-252

Ansell AD, Gibson RN (1990) Patterns of feeding and movement of juvenile flatfishes on an open sandy beach. In: Barnes $M$, Gibson RN (eds) Trophic relationships in the marine environment. 24th Eur Mar Biol Symp, Oban, 1989. Aberdeen Univ Press, Aberdeen, p 191-207

Bellan-Santini D, Dauvin JC (1988) Eléments de synthèse sur les Ampelisca du nord-est Atlantique. Crustaceana Suppl 13:20-60

Borowsky B, Aitken-Ander P (1991) Sexually dimorphic free-swimming behaviour in the amphipod crustacean Ampelisca abdita. J Mar Biol Assoc UK 71:655-663

Dauvin JC (1988) Biologie, dynamique et production de populations de crustacés amphipodes de la Manche occidentale. 1 Ampelisca tenuicornis Liljeborg. J Exp Mar Biol Ecol 118:55-84

Dauvin JC, Zouhiri S (1996) Suprabenthic crustacean fauna of a dense Ampelisca community from the English Channel. J Mar Biol Assoc UK 76:909-929

de Vlas J (1981) On cropping and being cropped. The regeneration of body parts by benthic organisms. In: Jones NV, Wolff WJ (eds) Feeding and survival strategies of estuarine animals. Plenum Press, New York, p 173-177

de Vlas J (1985) Secondary production by siphon regeneration in a tidal flat population of Macoma balthica. Neth J Sea Res 19:147-164

Dugan PJ (1981) The importance of nocturnal foraging in shorebirds: a consequence of increased invertebrate prey activity. In: Jones V. Wolff WJ (eds) Feeding and survival strategies of estuarine animals. Plenum Press, New York, p 251-260

Evans PR (1987) Adaptations shown by foraging shorebirds to cyclical variations in the activity and availability of their intertidal invertebrate prey. In: Naylor E, Hartnoll $R G$ (eds) Cyclic phenomena in marine plants and animals. 13th Eur Mar Biol Symp, Isle of Man, 1978. Pergamon Press, Oxford, p 357-366

Halcrow K (1988) Absence of epicuticle from the repair cuticle produced by four malacostracan crustaceans. J Crustac Biol 8:346-354

Halcrow K, Smith JC (1986) Wound closure in the crab Carcinus maenas. Can J Zool 64:2770-2778

Holling CS (1959) Some characteristics of simple types of predation and parasitism. Can Ent 91:385-398

Hughes DJ, Ansell AD, Atkınson RJA, Nickell LA (1983) Underwater television observations of surface activity of the echiuran worm Maxmuelleria lankesteri (Echiura: Bonellidae). J Nat Hist 27:219-248

Kanneworff E (1965) Life cycle, food and growth of the amphipod Ampelisca macrocephala from the Oresund. Ophelia 2(2):305-318

Klein G, Rachor E, Gerlach SA (1975) Dynamics and productivity of two populations of the benthic tube-dwelling amphipod Ampelisca brevicornis (Costa) in the Helgoland Bight. Ophelia 14:139-159

Luckenbach MW (1986) Sediment stability around animal 
tubes: the roles of hydrodynamic processes and biotic activity. Limnol Oceanogr 31:779-787

Mills EL (1967) The biology of an ampeliscid amphipod crustacean sibling species pair. J Fish Res Bd Can 24:305-355

Nowell A.RL, Church M (1979) Turbulent flow in a depthlimited boundary layer. J Geophys Res 84:4816-4824

Putman RJ, Wratten SD (1985) Principles of ecology. Croon Helm, London

Sanders HL (1956) The biology of marine bottom communities. Bull Bingham Oceanogr Coll 15:344-414

Sheader M (1977) Production and population dynamics of Ampelisca tenuicornis with notes on the biology of its parasite Sphaeronella longipes. J Mar Biol Assoc UK 57:955-968

Editorial responsibility: Otto Kinne (Editor),

Oldendorf/Luhe, Germany
Sheader M (1983) The reproductive biology and ecology of Gammarus duebeni (Crustacea: Amphipoda) in southern England. J Mar Biol Assoc UK 63:517-540

Summer RW (1980) The diet and feeding behaviour of the flounder Platichthys flesus in the Ythan estuary Aberdeenshire, Scotland. Estuar Coast Mar Sci 11. $217-232$

Trevallion A (1971) Studies on Tellina tenuis (da Costa) III Aspects of general biology and energy flow. J Exp Mar Biol Ecol 7:95-122

Wooding RA, Bradley EF, Marshall JK (1973) Drag due to regular arrays of roughness elements of varying geometry. Boundary-Layer Meteorol 5:285-308

Submitted: October 20, 1997; Accepted: January 13, 1998 Proofs received from author(s): March 9, 1998 